Jurnal Poetika Vol. IV No. 2, Desember 2016

\title{
PRODUKSI, DISTRIBUSI, DAN KONTESTASI \\ WACANA TRADISI DAN MODERNITAS \\ DALAM CERPEN Leteh KARYA OKA RUSMINI
}

\author{
Akmal Jaya \\ Universitas Gadjah Mada \\ akmal.jaya@gmail.com
}

\begin{abstract}
Abstrak
Penelitian ini bertujuan untuk mengungkapkan bagaimana wacana mengenai tradisi kebudayaan masyarakat Bali diproduksi, dipertentangkan dan kemudian menjadi wacana tandingan terhadap wacana modernitas dalam cerita pendek Leteh karya Oka Rusmini. Penelitian ini mengaplikasikan teori dan metode analisis wacana Foucault, dengan menampilkan formasi diskursif melalui ekslusi eksternal maupun internal. Penelitian ini menemukan bahwa ada upaya-upaya memproduksi, mendistribusikan, kemudian memodifikasi wacana tradisi sebagai wacana tandingan terhadap modernitas.
\end{abstract}

Kata Kunci: Wacana, Analisis Wacana, Formasi Diskursif, Ekslusi Ekternal, Ekslusi Internal.

\begin{abstract}
This research is aimed to show how discourse about tradition in Balinese are producted, contested, and being conterdiscourse toward modernity in Leteh short story by Oka Rusmini. Foucault's theory and method of discourse analisys are applied as an approach to reveal discourse of formations by external and internal exclutions. The results of this research show that Leteh was producing, distributing and modifying discourse of tradition as a counter discourse for modern discourse.
\end{abstract}

Keywords: Discourse, Discourse of Analysis, Discourse of Formation, External Exlution, Internal Exlution.

\section{Pendahuluan}

Saat ini, Bali merupakan salah satu destinasi wisata terpopuler dalam skala nasional maupun internasional. Wisata pantai, budaya, dan religi menjadi opsi yang senantiasa ditawarkan kepada wisatawan tiap kali mengunjungi pulau Bali. Oleh karenaitu, banyak wisatawan baik lokal maupun internasional datang berlibur Bali. Data yang dihimpun dari laman Dinas Pariwisata Pemerintah Provinsi Bali menunjukkan adanya peningkatan wisatawan asing yang mengunjungi Bali dari tahun 2014 dan 2015. Pada tahun 2014, wisatawan asing yang tercatat mengunjungi Bali berjumlah 3.766.638 wisatawan, sedangkan pada tahun 2015 tercatat 4.001.654 wisatawan yang mengunjungi Bali ${ }^{1}$. Data tersebut menunjukkan kuatnya arus gelombang orang asing yang datang ke Bali dan

\footnotetext{
1 Dinas Pariwisata Pemerintah Provinsi Bali. 2016. (daring) <www. disparda.baliprov.go.id /statistika/wisatawan-mancanegara>. diakses pada tanggal 23 Desember 2016. Pukul 18.15.
}

tentunya menyebabkan interaksi masyarakat Bali dengan wisatawan asing yang begitu intens.

Kedatangan para wisatawan tentunya memberikan dampak pada masyarakat Bali. Seperti yang diungkapkan oleh media lokal, BaliPost, pengaruh industri wisata pada sisi ekonomi masyarakat Bali menunjukkan adanya peningkatan positif, namun hal tersebut tidak beriringan dengan tingkat kesejahteraan masyarakat Bali ${ }^{2}$. Di sisi lain, tradisi kebudayaan Bali, dijelaskan oleh IDG Widhu Sancaya, dalam Bali, di Antara Tradisi dan Modernitas (2013), justru mendapat tantangan serius akibat datangnya kebudayaan asing (modern) yang dibawa/melekat oleh wisatawan asing. Besarnya pengaruh kebudayaan modern terhadap masyarakat Bali menjadi perhatian serius oleh para pemerhati kebudayaan, termasuk juga

\footnotetext{
2 IDG Windhu Sancaya. 2013. Bali, di antara Tradisi dan Modernitas. (daring) <http://balipost.co.id/mediadetail.php?module=detailopiniin dex\&kid=1\&id=7739> diakses pada tanggal 23 Desember 2016. Pukul 18:35.
} 
dalam hal ini para sastrawan. Terdapat sejumlah sastrawan dalam karyanya menceritakan tentang kondisi Bali saat ini. Melalui karyanya, sastrawan seakan menggiring satu pemahaman tentang tradisi dan juga modernitas. Upaya ini dianggap sebagai bentuk kritis terhadap kondisi masyarakat adat, khususnya Bali, yang dianggap kian tergerus oleh kebudayaan modern.

Artikel ini akan menganalisis satu karya sastra dalam bentuk cerita pendek karya Oka Rusmini berjudul Leteh, diterbitkan oleh KOMPAS pada 12 April 2015. Membaca cerita pendek karya Oka Rusmini yang berjudul Leteh sangat kental dengan simbol-simbol tradisi dan kepercayaan masyarakat Bali yang mayoritas beragama Hindu. Seperti dari namanama tokoh, bidadari, dewa, pura, dupa dan lain-lain. Leteh sendiri berasal dari bahasa Bali yang berarti kotor atau tercemar. Bahasa ini tidak serta merta berefenrensi pada suatu kondisi material, seperti air atau udara yang tercemar, namun juga cenderung lebih pada tindakan manusia yang dianggap menyimpang, bertentangan, melanggar adat atau kepercayaan masyarakat Bali. Bukan tidak mungkin, Oka Rusmini sengaja mengangkat tradisi Bali yang dikemas dalam sebuah bentuk cerpen. Sebuah upaya yang secara implisit memperlihatkan kondisi masyarakat adat Bali di tengah gejolak pengaruh kebudayaan asing. Oleh karena itu, artikel ini membawa satu pertanyaan tentang bagaimana wacana mengenai tradisi kebudayaan masyarakat Bali diproduksi, dipertentangkan dan kemudian menjadi wacana tandingan terhadap wacana modernitas dalam cerita pendek Leteh karya Oka Rusmini.

Dalam Archaelogy of Knowledge (1972:80), Foucault mendefenisikan wacana sebagai "general domain of statements", seperti kutipan pernyataan:

"Lastly, instead of gradually reducing the rather fluctuating meaning of the word 'discourse', I believe that I have in fact added to its meanings: treating it sometimes as the general domain of all statements, sometimes as an individualizable group of statements, and sometimes as a regulated practice that accounts for a certain number of statements".
Penjelasan Foucault dapat dipahami bahwa wacana terkadang menjadi domain umum dari segala pernyataan, terkadang sebagai pernyataan dari sekelompok individu, dan terkadang sejumlah praktik kebijakan bagi beberapa pernyataan.

Hal ini berarti bahwa wacana bisa merujuk ke segala pernyataan atau ungkapan yang dibuat yang memiliki makna dan efek. Pernyataan atau ungkapan tersebut dapat berupa sebuah pengelompokan; yaitu seperti hal yang lebih umum, contohnya "maskulinitas", jadi pernyataan atau ungkapan tersebut tidak hanya digolongkan kepada sebuah kalimat saja. Akan tetapi yang ditekankan oleh Foucault tentang wacana bukanlah teks (pernyataan atau ungkapan) tersebut, tetapi bagaimana teks tersebut diproduksi sehingga membentuk wacana yang kemudian mempunyai kekuatan.

\section{Ekslusi Eksternal}

Wacana tidak dibiarkan begitu saja, tetapi ada yang berperan mengendalikan atau bahkan menguasainya. Sehingga, wacana sering diasosiasikan dengan kekuasaan. Wacana memiliki kekuatan untuk mengopresi dan melawan. Oleh karena itu wacana tidak sesimpel menyamakannya dengan bahasa; dengan melihat hubungannya antara wacana dengan realitas. Akan tetapi wacana meliputi sebuah sistem yang membentuk cara bagaimana melihat sebuah realitas; karena kata atau kalimat tidak mengasosiasikan kepada apa yang diketahui (pengetahuan tertentu), tetapi justru apa yang membatasi apa yang kita persepsikan. Praktik untuk melanggengkan sebuah wacana yaitu dengan regularitas:

"A practice that imposes on them; it is in this practice that the events of discourse find the principle of their regularity... Thus, the regularitieswhich we perceive in realities should be seen as the result of anonymous regularities of discourse we impose on reality"(Mills, 2003: 56).

Regularitas yang dimaksud di sini berupa larangan. Seperti yang pernah Foucault sebutkan yaitu dalam prosedur produksi wacana adalah dengan eksklusi, yang berupa larangan (Faruk, 
2012: 242). Prosedur yang meliputi tiga macam eksklusi eksternal yaitu: "taboo, the different between mad and sane, and the distinction between true and false" (Mills, 2003: 57-8); atau juga disebut sebagai larangan objektif, larangan subjektif, dan larangan kontekstual (Faruk, 2012: 242).

Dari prosedur ekslusi eksternal di atas dapat ditemukan sebuah gambaran bagaimana sebuahwacanaberada, bertahandandimodifikasi dalam masyarakat. Sebagai contohnya adalah sesuatu atau objek yang dibicarakan dibatasi; hal-hal yang taboo membatasi cara masyarakat mengetahui apa yang mereka tahu. Kemudian, tidak semua orang dapat membicarakan hal tertentu; ini berkaitan dengan hak-hak eksklusif yang dimiliki subjek; contohnya adalah orang yang secara mental tidak sehat, apa yang dia katakan tidak dianggap/didengar. Yang ketiga adalah tentang salah dan benar atau larangan kontekstual, yaitu mengenai larangan yang biasa ada dalam ritual, atau Foucault menyebutkan dimana kuasa itu melihat "expert" (ahli) untuk menentukan benar dan salah; kebenaran adalah sesuatu yang didukung secara material oleh berbagai macam praktik dan institusi (Mills, 2003: 58). Seperti misalnya pernyataan seseorang akan dianggap benar apabila sesuai, cocok dengan pernyataan-pernyataan lain yang sah dalam sebuah masyarakat.

\section{Ekslusi Internal}

Selain eksklusi eksternal tersebut, wacana juga diproduksi melalui prosedur eksklusi internal yang menurut Foucault ada empat hal:

"Foucault also asserts that there are four internal proceduresof exclusion and these are: commentary; the author; disciplines; and the rarefaction of the speaking subject. These procedures are all concerned with classifying, distributing and ordering discourse, andtheir function is ultimately to distinguish between those who are authorized to speak and those who are not-those discourses which are authorized and those which are not. The first internal exclusion, commentary, is writing about another's statements. Thus, literary criticism can be considered to be commentary" (Mills, 2003: 58-9).

Seperti yang disebutkan dalam kutipan di atas bahwa empat hal dalam prosedur eksklusi internal juga memiliki fungsi yang sama yaitu mengontrol dan membatasi wacana. Prosedur ini dibutuhkan karena wacana-wacana itu sendiri melaksanakan kontrolnya sendiri (Faruk, 2012: 244). Seperti misalnya banyak orang menganggap bahwa suatu teks dikomentari dan didiskusikan karena teks tersebut menarik dan lebih dihargai dibandingkan dengan teks-teks yang lain. Peran dari commentary atau komentar, yaitu mengatakan apa yang ada dalam teks tersebut, dimodifikasi, diceritakan kembali, dan diulang. Kemudian muncul wacana baru yang dihubungkan dengan masa yang lebih kini, ditransformasikan dan dikatakan lagi secara tak terbatas. Oleh karena itu, komentar ini menjadikan wacana berada dalam sirkulasi sehingga dalam fungsi yang sama dan prinsip diferensiasi yang terus berlanjut (Mills, 2003: 59; Faruk, 2012: 245).

Prinsip yang kedua yaitu author atau pengarang, yang dimaksud dengan pengarang bukanlah individu yang berbicara, yang menuliskan teks, tetapi pengelompokan wacana. Seperti misalnya, seorang pengarang tertentu memproduksi banyak buku yang kemudian dari semua buku yang diproduksi tersebut menghasilkan suatu relasi antara buku yang satu dengan yang lain; melihat satu teks sebagai reaksi dari hal yang lainnya; meskipun pada akhirnya mungkin pengarang tersebut diatributkan, tetapi banyak juga wacana yang diturunkan tidak dari seorang pengarang yang diatributkan pada wacana tersebut. Contohnya dalam kutipan dibawah ini:

"Foucault is very critical of such notions as the progression of an authorfrom immaturity, early works to maturity or later works. If we discuss the 'early' works of Shakespeare, we should interrogate why it is that we are using such a metaphor, implying as it does that these works are less developed than his later texts, and we should simply analyse these texts in their own terms, rather than according to a fictional schema which we have of Shakespeare's life" (Mills, 2003: 60).

Pengarang diminta memperhitungkan kesatuan teks atas namanya; untuk mengungkapkan makna yang tersembunyi di dalam karyanya; 
mempertalikan antar karyanya dengan pengalaman pribadinya atau sejarah nyata yang mendorong kelahiran karya tersebut. Di sini pengarang menjadi titik koherensi dan jalan masuk ke dalam kenyataan.

Prinsip eksklusi internal selanjutnya yaitu disciplines atau disiplin. Pembatasan ini ditempatkan pada subject matter, atau hal yang dibicarakan. Sebuah disiplin harus memungkinkan perumusan pernyataanpernyataan baru; memegang apa yang dikatakan benar atau salah, batas aturan disiplin itu sendiri-di sinilah prinsip pembatasan (Faruk, 2012: 247). Melalui seperangkat metode dan pendekatan tertentu, suatu teks tersebut sudah terbatasi untuk dibicarakan hal yang tertentu saja yang sesuai dengan seperangkat metode dan pendekatan tersebut; karena disiplin tersebut memiliki seperangkat proposisi dan aturan yang dianggap faktual sehingga menghasilkan proposisi baru atau pernyataan baru tentang benar atau salah.

Prinsip eksklusi internal yang terakhir yaitu the rarefaction of the speaking subject. Yang dimaksud adalah pembatasan atas siapa yang berhak berbicara; beberapa wacana terbuka untuk semua orang dan beberapa yang lain terbatas.

Dari prosedur produksi wacana baik secara eksklusi eksternal maupun internal, kondisi aplikasi wacana dapat dipahami bahwa tidak semua wacana terbuka bagi semua orang, pembatasan-pembatasan yang berupa larangan atau peraturan tertentu menentukan antara salah dan benar; dan semua prosedur yang ada tersebut menjaga wacana tersebut berada dalam sirkulasi, yaitu diceritakan kembali, diturunkan, dimodifikasi, dan didistribusikan di dalam masyarakat tertentu.: ritual tutur, masyarakat wacana, doktrin, maupun apropriasi sosial saling berhubungan dan membentuk jenis pendidikan yang besar yang menjamin distribusi subjeksubjek yang berbicara ke dalam tipe wacana yang berbeda (Faruk, 2012: 250).

Pada intinya, wacana dapat dilihat sebagai istilah yang mengacu pada pernyataanpernyatan, aturan yang terbentuk dari pernyataan-pernyataan tersebut, dan melalui proses dimana pernyataan-pernyataan tersebut disirkulasikan dan pernyataan-pernyataan yang lain dieksklusikan.

"Thus, discourses should be seen as groups of statements which are associated with institutions, which are authorized in some sense and which have some unity of function at a fundamental level. The statement can be seen as an authorized proposition or action through speech" (Mills 1997).

"The statement is not simply a sentence because, for example, a map or image could be taken as a statement. The critics, Hubert Dreyfus and Paul Rabinow, argue that 'Maps can be statements, if they are representations of a geographical area, and even a picture of the layout of a typewriter keyboard can be a statement if it appears in a manual or as a representation of the way the letters of a keyboard are standardly arranged"(Mills, 2003: 65).

Wacana yang merupakan sekelompok pernyataan-pernyataan tentang topik yang sama juga memiliki efek yang sama yaitu dimungkinkan karena adanya tekanan institusional atau asosiasi dengan institusi tertentu.

\section{Bangkitnya Wacana Tradisi}

Leteh menceritakan tentang kondisi sebuah desa yang terkena kutukan. Matahari tidak pernah menyinari desa tersebut selama bertahun-tahun lamanya. Penduduk laki-laki di desa tersebut semuanya mati dengan kondisi yang mengenaskan. Tersisa satu laki-laki yakni seorang pemangku tua, seorang pendeta pura di desa itu. Kutukan dimulai ketika warga desa sudah tidak peduli lagi atau melupakan ritualritual tradisi kepercayaan yang ada sejak dulu, demi mengumpulkan kekayaan dunia. Desa yang sudah tercemar oleh kedatangan para investor yang membangun dengan seenaknya. Prilaku penduduk desa yang gemar menyuap, korupsi, menyebabkan alam murka dan mengutuk desa dan penduduknya.

Namun semuanya mulai berangsur pulih semenjak lahirnya I Wayan Kobar atau biasa dipanggil Pan Kobar. Lahir dari seorang wanita yang bisu, tuli, dan buta tanpa diketahui siapa ayahnya. Begitu juga dengan munculnya seorang pemudi asing yang entah dari mana 
asalnya. Pemudi tersebut ditemukan oleh warga desa dalam keadaan terikat di pohon pule dengan kondisi yang mengenaskan, penuh luka dan berbau amis. Pemudi tersebut kemudian dimandikan dan disucikan oleh warga sesuai dengan perintah pemangku adat dan diberi nama Ni Lub Wayan Arimbi. Munculnya sepasang manusia ini memunculkan harapan baru bagi masyarakat desa akan keberlangsungan hidup penerus di desanya. Matahari kembali mulai menyinari desa tersebut, orang-orang dari desa lain kini mulai berani untuk datang ke desa. Penduduk berharap I Wayan Kobar yang tampan bertubuh kekar dambaan perempuan desa dan Ni Lub Wayan Arimbi yang cantik layaknya Ken Dedes dambaan pria-pria kampung sebelah dapat bersatu dalam sebuah mahligai rumah tangga. Meskipun hingga akhir cerita mereka hanya saling mengenal tidak membina rumah tangga.

Dalam cerpen ini, terlihat bagaimana keadaan masyarakat Bali yang diibaratkan sebagai penduduk desa di cerpen tersebut mengalami kutukan dari para dewa. Kutukan akibat meninggalkan/melupakan adat istiadat kepercayaan agama karena terlena akan urusan duniawi. Keadaan ini merupakan refleksi pengarang atas apa yang terjadi pada masyarakat Bali dewasa ini, dan tentunya, melalui cerpen ini ada upaya dari Oka Rusmini untuk mencoba mengangkat satu wacana akan pentingnya tradisi-tradisi yang mengandung nilai-nilai lokalitas. Sehingga, ketika hal tersebut dilakukan maka ada upaya untuk mereligitimasi melalui wacana yang diproduksi, diseleksi, dikontrol, dan didistribusikan oleh masyarakat tersebut.

\section{Ekslusi Eksternal}

\section{Larangan Subjektif : Between Mad and Sane}

Berdasarkan prinsip eksklusi eksternal, wacana dibentuk dan dipertahankan melalui larangan-larangan yang membatasi cara pandang apa yang masyarakat sebenarnya sudah tau. Yang pertama yaitu larang subjektif, sebagaimana disebutkan oleh Mills (2003) bahwa larangan subjektif mengacu pada siapa yang menyatakan, between mad and sane, yaitu terpusat pada subjek, sehingga menyangkut hak untuk berbicara mengenai segala sesuatu. Pernyataan orang yang gila (mad) atau sakit jiwa tidak dianggap, tidak dipercaya. Penolakan terhadap kebenaran yang disaksikan oleh seorang yang gila menjadikan mereka tidak berhak untuk menyatakan/berbicara tentang segala hal.

Dalam cerpen ini, ada beberapa larangan subjektif dalam bentuk pernyataan yang terjadi. Baik itu antara sesama warga ataupun warga dan sesepuh desa. Dari pernyataan tersebut nampak jelas bagaimana hal tersebut coba dipertentangkan satu sama lain, antara tradisi dan prilaku modern. adapun pernyataannya sebagai berikut:

"kalau alam jadi kacau begini, apa yang harus dillakukan?. "haturkan sesaji besar. Mungkin kalau diberi upeti, alam mau kompromi".

"ngawur. Memangnya alam itu kayak politisi atau pejabat yang bisa disogok?"

"siapa tabu. Namanya juga usaha. Patut dicoba. Bukankah begitu budaya yang dicontobkan para pemimpin negeri kita? Istilahnya, gotong royong..."

Peryataan di atas menunjukkan bagaimana tradisi dan modernis dipertentangkan, diantaranya:

\section{a. Alam dan Pejabat Korup}

Pertentanganterjadipadapenggambaran tradisi kebudayaan dan modernitas yang disimbolkan dengan alam yang kacau. Tradisi semestinya digambarkan oleh harmonisasi antara manusia dan alam, yakni ketika manusia senantiasa menjalankan serta mengikuti nilainilai tradisi. Kekacauan alam menandakan bagaimana manusia melupakan bahkan mengkritisi tradisi yang selama ini bersifat taken for granted sebagai dampak dari pengaruh modernitas. Sehingga alam yang kacau adalah pertempuran antara tradisi dan modernitas. Namun di sisi lain, ada relasi tak setara dalam kutipan di atas, yakni Alam dan Pejabat Korup. Alam yang merupakan metaforis dari tradisi mendapat kedudukan yang lebih tinggi dibandingkan dengan Pejabat yang merupakan metaforis dari modernitas. Alam dianggap lebih bermartabat, suci, dan terhindar dari prilaku 
kotor. Berbeda dengan pejabat korup, yang terkadang secara berjamaah (gotong royong) melakukan tindakan tidak terpuji.

Dari relasi yang tidak setara antara alam dan pejabat korup dapat dipetakan posisi orang gila (mad) dan waras (sane). Pejabat yang melakukan tindakan korup (mad) yang mengakibatkan kekacauan sosial, negara, dan menyengsarakan rakyat dilakukan karena mereka tidak mempunyai kesadaran (sane) akibat meninggalkan nilai-nilai tradisi.

\section{b. Sesajen dan Sogokan}

Pertentangan yang juga muncul yakni antara tradisi sesajen dan sogokan. Bagi kaum modern, yang mengutamakan rasionalitas, kegiatan untuk menghaturkan sesajian kepada alam dianggap sebagai suatu tindakan yang siasia. Namun dari sudut pandang tradisi, tindakan tersebut disamakan dengan kegiatan kompromi, korupsi, kolusi, dan nepotisme yang lumrah dilakukan oleh para pejabat yang notabene merupakan kaum-kaum modern. Dalam kondisi ini, Alam yang sebelumnya ditempatkan lebih tinggi kini disamakan dengan Pejabat yang korup. Prilaku menghaturkan sesaji besar kepada alam dan dewa-dewa dianggap sebagai tindakan yang ngawur yang dilakukan oleh para orang gila $(m a d)$, sehingga orang waras (sane) tidak melakukan hal tersebut. Hal ini secara tidak langsung merupakan bentuk dari upaya yang mencoba menegasikan prilaku tradisi yang selama ini dilakukan oleh masyarakat di desa tersebut. Namun, pernyataan di atas juga merupakan pertarungan posisi gila dan waras, prilaku tradisi yang dianggap gila sebenarnya juga dilakukan oleh orang-orang waras. Sehingga antara gila dan waras menjadi kabur. Pada kondisi ini tergambarkan bahwa kuasa atas atas wacana yang tercipta, tersebar dan tidak secara penuh dikendalikan oleh satu pihak. Hal ini dapat diidentifikasi bagaimana para tokoh yang terlibat dalam pembicaraan tersebut tidak secara serta merta menerima (taken for granted) melainkan masing-masing pihak masih mengeksplorasi kemungkinankemungkinan lain di dalamnya sehingga pernyataan-pernyataan yang timbul bersifat antagonistik satu sama lain.

\section{c. Legenda dan Rasionalitas}

Kutipan berikut mempertentangkan antara legenda/mitos dan rasionalitas:

Azab apa lagi yang akan mendera mereka jika ada perempuan di desa itu yang hamil tanpa suami? "mungkin hamil sendiri. Bukankah Kunti bisa melabirkan Karna tanpa disentuh laki-laki?" ujar seorang perempuan.

"siapa bilang?" bantah perempuan lain. "Kunti tentu bersentuhan dengan laki-laki. Dia memang bilang dia tidak berbubungan dengan laki-laki. Tapi bagaimana kalau dia bohong untuk menutupi aib? Mungkin dia main sama pacarnya yang tidak bisa dia miliki."

"Benar juga,"dukung perempuan lain. "mungkin Kunti Cuma mengarang cerita sebagai trik supaya selamat. Biar lolos dari cibiran. Aku sudab lama jadi perempuan. Aku tabu bagaimana cara mengakali perkara begituan. Kalau dilukai, perempuan bisa menjelma jadi makhluk paling jahat di muka bumi. Bisa menghancurkan apa saja. Apalagi perempuan kayak Kunti. Perempuan cerdik. Semua cerita itu cuma taktik supaya dia tetap dipandang suci."

Mangku Siwi mengangkat dupa tinggi-tinggi

"seorang lelaki akan labir di desa ini," ujarnya lirih.

Hamilnya Kunti tanpa bersentuhan dengan lelaki merupakan sebuah legenda/cerita rakyat (tradisi) dalam masyarakat Bali. Hal tersebut kemudian dipertentangan dengan rasionalitas (modern) dalam artian bahwa seorang wanita tidak mungkin hamil tanpa melakukan hubungan seksual (bertemunya sel telur dan sperma) dengan laki-laki. Dari kutipan tersebut, diperlihatkan kecenderungan modernitas yang menganggap hal-hal yang irrasional sebagai bentuk ketidak-warasan (madness), dan sebaliknya yang rasional merupakan bentuk kewarasan (sane).

Namun, bila diperhatikan kutipan di atas nampak bahwa posisi tradisi kembali ditinggikan. Pura, dupa yang ditinggikan, dan Mangku Siwi, merupakan representasi metaforis tradisi kebudayaan masyarakat Bali. Sejumlah warga yang mendatangi pura, dan kemudian bertanya kepada seorang pendeta/pemangku adat di desa yang serta merta diakui sebagai satu-satunya penyelamat warga, dan di akhir 
kutipan tersebut, tanpa menjawab pertanyaan warga, sang pendeta hanya mengangkat dupa tinggi-tinggi. Gambaran ini seakan-akan menyiratkan bahwa ada wilayah-wilayah dalam tradisi masyarakat Bali yang begitu tinggi sehingga rasionalitas tak mampu mencapainya. Wilayah-wilayah tersebut hanya dapat dicapai/ dipahami oleh kalangan ahli, seperti Mangku Suwi. Sehingga kepahaman atas hal-hal yang tidak dimengerti sebagai bentuk kewarasan (sane) melekat pada Mangku Suwi, sedangkan yang tidak memahami tergolong pada kategori gila (mad). seperti kutipan berikut ini :

"Mangku Siwi terlalu mencintai Kosmis, Otak dan hatinya hanya berisi mantra-mantra. Semua yang bergerak, segala yang berdetak, ditangkapnya sebagai sasmita untuk, kelanjutan bidup desanya".

kutipan di atas menunjukkan kuasa penuh terletak pada seorang pemangku adat yang padanya melekat status ahli (expert). Seperti Foucault sebutkan bahwa kekuasaan itu dipengaruhi dari pengetahuan, pengetahuan sebagai seorang pemangku adat di desanya. Sehingga wacana yang dihasilkan pada saat itu tidak menimbulkan pertanyaan lagi atau prilaku eksplorasi seakan menghilang. Adanya perbedaan dari masing-pasing kondisi terhadap satu wacana mengindetifikasi bahwa hal ini merupakan hasil upaya Oka Rusmini dalam menggiring wacana mengenai tradisi sebagai wacana tandingan atas modernitas.

\section{Larangan Objektif : Taboo}

Taboo merupakan larangan yang menjadikannya tidak sembarangan untuk dibicarakan dan juga membatasi bagaimana orang membicarakan objek/hal tersebut:"Taboo is a form of probibition since it makes it difficult to speak about certain subjects such as sexuality and death and constrains the way that we talk about these subjects" (Mills, 2013: 58). Dari hal tersebut, terdapat halhal yang dianggap taboo menjadi perbincangan dalam cerpen Leteh ini:

\section{a. Hamil tanpa Ayah}

"Kelabiran? Siapa yang melabirkan? Bukankan sudah tidak ada lelaki di desa ini?" [...]. "Nunas iwang, Jero Mangku. Mohon maaf. Bolebkah kami tahu, siapa perempuan yang mengandung? Apakah ada lelaki datang ke desa ini dan meyentub salah satu perempuan tanpa kami ketahui?"

Wajah perempuan-perempuan itu terlihat ketakutan. Alam telah menghukum mereka dengan kejam. Azab apa lagi yang akan mendera mereka jika ada perempuan di desa itu yang hamil tanpa suami?

Mangku Siwi hanya membisu".

Konteks taboo dalam kutipan di atas dipertentangkan dalam kerangka tradisi dan modern. Bagi kaum masyarakat desa (modernis), lahirnya seorang anak tanpa diketahui ayahnya merupakan sebuah penistaan, kotor, dan hina. Hal ini kemudian merujuk pada prilaku seksual bebas. Di sisi lain bagi kalangan penganut ajaran tradisional yang mistis (pemangku adat), hal tersebut juga merupakan sesuatu yang taboo, namun dalam konteks kerohaniawan, peristiwa ini menjadi keputusan Sang Dewa dan bersifat suci. Sehingga bagi kedua posisi ini, kelahiran tanpa ayah merupakan hal yang taboo namun berbeda dari segi nilai dan norma. Batasanbatasan atas objek pembicaraan kemudian diformulasikan, didistribusikan melalui kehidupan masyarakat desa.

Apabila seseorang melahirkan anak tanpa diketahui siapa ayahnya menjadi suatu hal yang taboo dan tentunya hal tersebut dipandang sebagai suatu yang Leteh dalam masyarakat desa, maka tidak serta merta pembicaraan bisa dikaitkan dengan objek tersebut, dan tentunya wacana akan lahirnya seseorang tanpa ayah semakin menguat dilingkungan masyarakat desa. Jika dalam masyarakat modern yang rasional tiap orang lahir pasti memiliki ayah dan ibu, namun apabila kelahiran tanpa ayah benar terjadi maka hal tersebut dikaitkan dengan suatu hal yang irrasional, mistis, yang cenderung melekat pada tradisi leluhur.

\section{Larangan Kontekstual: True and False}

Larangan kontekstual berkaitan dengan ritual, apa yang membenarkan dan mempersalahkan sesuatu. Sebuah pernyataan akan menjadi benar apabila disahkan dengan 
pernyataan-pernyataan lain yang sesuai atau cocok dengan apa yang ada di dalam masyarakat tersebut, seperti misalnya sesuai dengan ritual tertentu. Konteks di sini juga berkaitan dengan institusi; salah dan benar berkaitan dengan institusi yang mengesahkannya. Hal ini juga berlaku pada cerpen Leteh ini. Ada banyak simbol-simbol tradisi masyarakat desa yang terinstitusi menciptakan satu klaim kebenaran yang kemudian bersifat taken for granted oleh masyarakat desa. Masalah Leteh (kotor, tercemar, atau tidak suci) sebagai suatu hal yang berhubungan dengan kepercayaan masyarakat hindu Bali saat ini banyak diperbincangkan.

Seperti pada majalah Raditya, sebuah majalah Hindu yang ada di Bali mengupas fenomena Leteh ini. Ditulis oleh I Wayan Miasa dengan judul Leteh di Sini Leteh di Situ: Kontradiksi dalam Kebidupan Masyarakat Bali (2010), mengungkapkan bahwa masyarakat Bali kini tidak memahami/atau bahkan melupakan tradisi kepercayaan Hindu, sehingga menimbulkan ketidak sucian Jiwa. Seperti satu kasus yang dituliskannya:

"Contoh lainnya adalah kontradiksi kafe dan pesraman. Kafe-kafe yang kemudian banyak menjurus pada pelanggaran bukum: minum-minuman keras, prostitusi, narkoba dan lain-lain temyata begitu mudah mendirikannya di lingkungan desa pakraman. Tetapi ada sejumlah kasus, jika umat Hindu hendake. membangun pesraman, maka banyak dalih dilontarkan untuk menghambatnya".

Dari hal tersebut tampak jelas bagaimana pertentangan antara nilai tradisi dengan kebudayaan modern dalam masyarakat Hindu Bali. Pengaruh kebudayaan modern saat ini dapat dilihat dari hasrat masyarakat Bali yang lebih condong mengarah kepada urusan duniawi. Mengejar hal-hal yang secara praktis menghasilkan uang. Dibangunnya kafe-kafe yang secara tidak langsung akan menimbulkan tindakan-tindakan tercela seperti mabukmabukan, prostitusi, narkoba dll. Sedangkan kegiatan-kegiatan tradisi masyarakat seperti membangun sarana ibadah justru mendapat hambatan dari masyarakat itu sendiri. Kemudian I Wayan menambahkan kontradiksi masyarakat
Bali yang lainnya:

"Apa beda penggalian dana lewat sabungan ayam dengan penggalian dana undian berhadiah. Bedanya adalah, kalau undian berhadiah jelas ada transaksi jual-beli. Kalau beruntung ya dapat hadiah, tetapi kalau tidak ya tak apa-apa. Nab, kalau penggalian dana lewat sabungan ayam jelas ada unsur kalah menang dan ada yang dikorbankan.Bila penggalian dana lewat sabungan ayam diijinkan terus, mungkin suatu saat akan ada penggalian dana lewat lokalisasi, membuat bazzar dengan layanan cewek kafe, penari striptease dan lain-lain".

Begitu juga dengan kebiasaan sabung ayam oleh masyarakat Bali. Sabung ayam memang merupakan bagian tradisi kebudayaan masyarakat Bali, Namun hal tersebut seakan menjadi arena perjudian berkedok pengumpulan dana. Apalagi, tak jarang sabung ayam justru menghasilkan pertikaian antar warga. Kemudian perlakuan yang diterima oleh pemangku adat yang saat ini terkadang tidak diperhatikan lagi.

"Dalam kehidupan kita juga terasa hal yang agak kontradiktif dengan kebidupan Pemangku, Pedanda dan sulinggih lainnya. Pemangku-pemangku di pura sering bldupnya tak diperhatikan, babkan akan lebih parah lagi bila beliau dari keluarga tak mampu semakin sulit bidupnya. Dibatasi oleh larangan ini larangan itu tentang sesana kepemangkuan.Hal berbeda terjadi pada kehidupan sulinggih, seorang yang meraga putus tapi masib suka memakai perbiasan emas di jari-jarinya".

Pergeseran orientasi masyarakat Bali tentu berdampak pada kehidupan pemangku adat yang semakin terpinggirkan. Hal ini tidak lain karena masyrakat tidak lagi peduli akan tradisi nenek moyang. Sehingga kebutuhan akan kerohaniawan cenderung diacuhkan. Pengaruh modernisasi dan masuknya pengaruh asing sebagai konsekuensi daerah wisata menimbulkan persoalan baru bagi masyrakat Bali, yakni tergerusnya kepercayaan akan tradisi nilai-nilai lokalitas.

Oka Rusmini kemudian menuangkan 
hal tesebut dalam cerpen Leteh di mana tradisi kembali memperoleh tempat dikalangan masyarakat Bali yang sebelumnya tenggelam oleh arus modernisasi. Masyarakat dalam cerpen tersebut kembali menempatkan atau memperhatikan simbol-simbol lokalitas, seperti pura, dan pemangku adat sebagai simbol institusional dalam mengambil keputusan.

Seperti pada kutipan berikut :

"laki-laki yang tersisa di desa itu tinggal seorang pemangku tua. Mangku Siwi, demikian warga desa biasa menyebut pendeta pura desa itu. Sesunggubnya sudah lama Mangku Siwi menyampaikan pawisik bahwa desanya akan mengalami serentetan kejadian aneh yang buruk. Namun tak ada yang percaya. Orang-orang di desa hanya sibuk memperkaya diri. Ingin cepat bidup enak dengan menjual tanah warisan. Sudah lama pura dan subak tidak berfungsi dengan semestinya. Lahan desa makin marak ditumbubi pobon beton".

Hingga pada akhirnya, kutukan pada desa itu terjadi, dan Mangku Siwi merupakan satu-satunya tempat untuk memperoleh petunjuk. Dalam artian ini, kelembagaan akan klaim kebenaran berada pada institusionalitas seorang pemangku adat. Dengan demikian, apa yang dikatakan oleh Mangku Siwi terhadap warga desa menjadi satu kebenaran atas apa yang terjadi dan akan dilakukan oleh warga desa. Posisi Mangku Siwi berada pada posisi seorang ahli atau expert pada kebudayaan-kebudayaan masyarakat desa di dalam cerpen itu.

Menyatakan sebuah kebenaran juga institusional, yaitu didukung oleh institusi tertentu sebagaimana Foucault menyebutkan "...it is always possible one could speak the truth in a void; one would onlybe "in the true" however if one obeyed the rules of some discursive "police" which would have to be reactivated every time one spoke" (1972:224). Secara institusional, kebenaran yang melekat pada seorang ahli yakni Mangku Siwi didukung oleh pengetahuan dan kuasanya sebagai pemangku adat. Pengetahuan dan kuasanya memberikan keabsahan terhadap apa yang ia katakan dan ia lakukan dan kemudian berterima pada masyarakat desa.

"Para perempuan itu berharap Mangku Siwi membocorkan rahasia yang dititipkan alam padanya. Mereka tabu, sang pemangku bisa membaca pertanda. Dialah satu-satunya tempat para perempuan itu minta petunjuk atau minta tolong".

Pengungkapan kebenaran yang dilakukan oleh Mangku Siwi menggunakan konsep-konsep tradisi masyarakat Hindu Bali yakni melalui mitos. Dan secara kontekstual hal itu berterima kebenaranya oleh masyarakat desa. Dari prinsip pembentukan wacana tersebut ditunjukkan bagaimana wacana dalam klaim kebenarannya diterima secara natural.

\section{Ekslusi Internal}

\section{a. Komentar}

Wacana-wacana akan pentingnya tradisi yang telah terbentuk dalam cerpen ini didukung oleh fakta dilapangan. Seperti apa yang telah disebutkan oleh Foucault tentang komentar; ada kebenaran-kebenaran lain yang dibentuk untuk mengulangi wacana yang telah ada, memperhalus, dan medistribusikannya kembali pada masyarakat wacana tersebut. Berbagai hal yang dianggap Leteh dalam masyarakat adat Bali disucikan melalui proses adat pula. Seperti pada kasus hubungan seksual antara ayah dan anak kandungnya sendiri, yang diangkat oleh media massa lokal Bali, Bali-editor.com. Pada laman berita tersebut, kejadian ini dianggap mencemarkan Desa Sudaji dan harus diadakan proses adat untuk mensucikan kembali.

"Upacara inpun dilBodbikan, berdasarkan surat pernyataan, GPY tegas mengBodhii perbuatannya telah berbubungan badan, dan sanggup melaksanakan segala tuntutan Desa Adat Pakraman Sudaji, melaksanakan pemrayascita atau membersibkan segala kotoran di wilayah Desa Adat Sudaji, yang dilBodbikan selama 2 hari yakni, 22 bingga 23 September, di perempatan agung Desa Sudaji, yang ditandatangani berisi materai 6000, dan pernyataan apabila tidak melaksanakan tuntutan Desa, maka siap diasingkan dari Desa Sudaji’3.

\footnotetext{
${ }^{3}$ Bali-editor.com. 2013. Desa Sudaji Leteh, Warga Pertanyakan tak Hadirnya GPY dan LSCD dalam upacara. (daring).<http://balieditor.com/ desa-sudaji-leteh-warga-pertanyakan-tak-hadirnya-gpy-dan-lscd-dalam-upacara>. diakses pada tanggal 23 Desember 2016. Pukul 22:45.
} 
Kutipan di atas menunjukkan adanya proses penyucian dari tindakan-tindakan yang dianggap Leteh oleh tradisi dan kebudayaan masyarakat Bali. Penyucian melalui upacara tradisi dianggap penting, hal ini dikarenakan agar jiwa yang kotor tidak mencemari jiwajiwa yang lain yang masih dianggap suci. Wacana penyucian ini merupakan satu bentuk modifikasi dari wacana akan pentingnya tradisi. Ada banyak tulisan mengenai pengaruh kebudayaan modern terhadap masyarakat Bali, seperti pada majalah Raditya, sebuah majalah Hindu yang ada di Bali mengupas fenomena Leteh ini. Ditulis oleh I Wayan Miasa dengan judul Leteh di Sini Leteh di Situ: Kontradiksi dalam Kehidupan Masyarakat Bali (2010) yang telah saya kutip pada bagian True and False.

\section{b. Pengarang}

Terdapat banyak tulisan mengenai tradisi lokal di Indonesia. Tulisan-tulisan tersebut kemudian menjadi satu kelompok tulisan yang mempunyai kesatuan prinsip pada pernyataan-pernyataan tertentu. Dalam hal ini, tulisan mengenai kebudayaan masyarakat Bali. Dalam kesusastraan, kesatuan akan wacanawacana yang tersebar dapat diatributkan pada pengarangnya (Faruk, 2012:246). Seperti sastrawan Oka Rusmini, dalam beberapa karyanya memang banyak membahas mengenai tradisi masyarakat Bali. Karya-karya tidak hanya monoton pada kegelisahan akan hilangnya nilainilai budaya Bali, bahkan juga lebih cenderung mengkritisi kebudayaan tersebut, khususnya masalah perempuan. Karya-karyanya yang mengangkat tema-tema tradisi kebudayaan Bali seperti : Tarian Bumi (2000), Kenanga (2003), Tempurung (2010), kumpulan cerpen Sagra (2001), dll.

\section{c. Disiplin}

Menurut Faruk (2012:257), persoalan disiplin lebih dekat dengan wacana ilmu pengetahuan daripada wacana kesusastraan. Meskipun demikian bukan tidak mungkin dalam kesusastraan terdapat satu disiplin didalamnya. Pertemuan antara dua kebudayaan yang berbeda, dalam konteks sastra Indonesia lebih cenderung dibahas dalam kerangka sastra poskolonial. Dalam kerangka ini, dua kebudayaan dipertemukan dengan kecenderungan adanya hierarki pada relasi dua kebudayaan tersebut, ataupun dalam konsep Bhaba (1994:25), disebut munculnya ruang ketiga (third space) yang padanya konsep hibriditas terwujud. Berkaitan dengan cerpen ini, tradisi kebudayaan Bali dihadapkan dengan kebudayaan modern sebagai konsekuensi dari destinasi wisata. Dalam hal ini, negosiasi terjadi antara kebudayaan masyarakat Bali dan wisatawan asing beserta budaya yang melekat padanya. Dari negosiasi tersebut dapat dilihat bagaimana hierarki yang terjadi atau adanya hibriditas yang mencakup sikap ambivalen, mimicry, resistensi atau bahkan subversive pada masyarakat Bali.

\section{Kondisi Aplikasi \\ a. Ritual}

Pada cerpen ini, ditemukan beberapa konteks yang mengarahkan pada pengkualifikasian yang menentukan siapa yang berhak dan tidak untuk berbicara, gerakgerik, prilaku, lingkungan, dan perangkat yang menyeluruh yang harus menyertai wacana. Seperti pada kutipan:

"Pada suatu hari, para perempuan berkumpul di pura desa

"Tero Mangku Siwi, bagaimana nasib desa kita? Apa yang harus kita lBodhikan?"

"Saat ini kita hanya menunggu kelabiran."

"Kelabiran? Siapa yang melabirkan? Bukankan sudah tidak ada lelaki di desa ini?"

Para perempuan itu berbarap Mangku Simi membocorkan rahasia yang dititipkan alam padanya. Mereka tahu, sang pemangku bisa membaca pertanda. Dialah satu-satunya tempat para perempuan itu minta petunjuk atau minta tolong".

Pada kutipan ini, nampak kualifikasi yang dimaksud secara penuh terletak pada tokoh MangkuSuwi.Segenap prilakudanlingkungannya ditentukan oleh keputusannya. Hal tersebut didasari atas kekuasaan yang dimiliki sebagai tokoh (expert) dalam pembentukan sebuah wacana. 


\section{b. Persahabatan Diskursus (Masyarakat Wacana)}

Dalam cerpen ini, masyarakat wacana terbentuk dari relasi wanita-wanita desa dengan sang pemangku adat. Wacana disediakan dan didistribusikan dalam sebuah ruang desa yang terkutuk oleh relasiantara tokoh di dalam cerpen. Seperti kutipan sebelumnya, para perempuan itu berharap Mangku Siwi membocorkan rahasia yang dititipkan alam padanya. Mereka tahu, sang pemangku bisa membaca pertanda. Dialah satu-satunya tempat para perempuan itu minta petunjuk atau minta tolong. Dari kutipan di atas, relasi yang terjalin hanya pada warga desa dengan pemangku adat. Kelahiran tanpa ayah kemudian tersebar, dimodifikasi dengan legenda/cerita rakyat Kunti. Distribusi, modifikasi, serta proteksi atas wacana kelahiran tanpa ayah dipelihara dalam masyarakat sekitar. Seperti kutipan berikut :

"mungkin hamil sendiri. Bukankah Kunti bisa melabirkan Karna tanpa disentuh laki-laki?" ujar seorang perempuan.

"siapa bilang?" bantah perempuan lain. "Kunti tentu bersentuban dengan laki-laki. Dia memang bilang dia tidak berhubungan dengan laki-laki. Tapi bagaimana kalau dia bohong untuk. menutupi aib? Mungkin dia main sama pacarnya yang tidak bisa dia miliki."

\section{c. Doktrin}

Pada cerpen ini, ada beberapa kutipan yang menunjukkan penanaman doktrin pada masyarakat desa. Doktrin yang disebar secara terbatas berdampak pada pengakuan/ kesetiaan akan wacana yang shahih. Seperti kutipan sebelumnya menunjukkan relasi antara pemangku adat dengan ritualnya terhadap masyarakat desa. Kesetiaan yang terjadi pada masyarakat desa terhadap pemangku adat tidak lepas dari wacana yang berkesesuaian bahwa pemangku adat berhubungan langsung dengan sang dewa. Sehingga apa yang dibicarakan oleh pemangku adat akan berterima dan tidak dipersoalkan oleh masyarakat desa.

\section{d. Apropiasi Penyisihan Wacana}

Pada tahap ini, wacana kemudian dapat dimodifikasi dan cenderung dipolitisasi oleh pengetahuan. Dengan demikan, wacana yang terbentuk kemudian dipertentangkan, dioposisikan, dimodifikasi melalui pengetahuan dengan cara politis. Pada kutipan-kutipan sebelumnya di atas, wacana tradisi dalam konteks mistis dipertentangkan melalui pengetahuan. Pengetahuan yang diperoleh dari pendidikan mengenai kehamilan tanpa hubungan seksual dipertanyakan. Namun untuk mempertahankan wacana tradisi tersebut, maka dihubungkan dengan legenda/cerita rakyat (kunti).

\section{Kesimpulan}

Dari analisis yang telah dipaparkan di atas nampak bahwa ada upaya-upaya memproduksi, mendistribusikan, kemudian memodifikasi wacana tradisi sebagai wacana tandingan terhadap modernitas. Melalui cerpennya, Oka Rusmini mencoba menggoyang kemapanan wacana kebudayaan modern yang saat ini melekat pada masyarakat Bali. Satu upaya dengan menghadirkan wacana-wacana tradisi dalam cerpen tersebut, kemudian dipertentangkan dengan wacana modernitas. Sebagai bentuk kritik atas budaya modern, Oka Rusmini kemudian menempatkan dirinya pada wacana yang selama ini terpinggirkan yakni wacana tradisi. Wacana mengenai pentingnya tradisi-tradisi lokal khususnya tradisi masyarakat Bali diproduksi melalui prinsipprinsip ekslusi baik eksternal maupun internal: seperti pelarangan subjektif yang terjadi antara penduduk desa, larangan objektif atau taboo, dan larangan kontekstual. Disamping itu ada beberapa dokumen faktual yang kemudian menjadi komentar mengenai masyarakat Bali dewasa kini yang semakin jauh dari nilainilai tradisi lokal. Hal ini juga mendukung terbentuknya wacana dan tentunya bagian dari struktur produksi wacana.

\section{Daftar Pustaka}

Bhaba, Homi K. 1994. Location Of Culture. Routledge:London

Faruk. 2012. Metode Penelitian Sastra: Sebuah Penjelajahan Awal. Pustaka Pelajar: Yogyakarta.

Foucault, Michel. 1972. The Archaelogy of Knowledge. (trans. A. M. Sheridan 
Jurnal Poetika Vol. IV No. 2, Desember 2016

Smith). London. Routledge.

Miasa, I Wayan. 2010. Leteh Di Sini Leteh Di Sana

: Kontradiksi dalam Kehidupan Masyarakat

Bali. (dalam Majalah Raditya Edisi

159). Raditya Perc. : Bali.

Mills, Sara. 2003. Routledge Critical Thinkers:

Michel Foucault. Taylor \& Francis group:

London and New York.

Rusmini, Oka. 2015. Leteh (dalam KOMPAS 12 April 2015) Kompas : Jakarta.

\section{Sumber Daring}

http:/ / balieditor.com/desa-sudaji-letehwarga-pertanyakan-tak-hadirnya-gpydan-lscd-dalam-upacara

http://www.disparda.baliprov.go.id/statistika/ wisatawan-mancanegara

http://balipost.co.id/mediadetail.php?module $=$ detailopiniindex\&kid $=1 \& i d=7739$

http://balipost.co.id/mediadetail.php?module $=$ detailberitaindex\&kid=1\&id $=66016$ 